\title{
The Relationship between Students' Reflective Thinking Skills and Levels of Solving Routine and Non-routine Science Problems
}

\author{
Zeynel Kablan*, Aslıhan Günen \\ Department of Curriculum and Instruction, Educational Sciences, Kocaeli University, Kocaeli, Turkey \\ *Corresponding Author: zeynel.kablan@kocaeli.edu.tr
}

\section{ABSTRACT}

Reflective thinking skills are thought to be an important factor affecting the success of problem solving both routine and non-routine science problems. This research aimed to determine the relationship between eighth-grade students' reflective thinking skills toward problem-solving and their level of solving routine and non-routine science problems. Determining this relationship can form a basis for the decisions teachers make in courses and contribute to increasing teaching quality. A correlational and regressional research design was used in this study. A total of 408 eighth-grade students from four secondary schools in Kocaeli, Turkey, constituted the sample group. The correlational results showed that as the students' reflective thinking toward problem solving scores increased, which were identified as questioning, reasoning, and evaluating, their level of solving routine and non-routine problems also increased. However, multiple regressional results showed only the evaluation skill was a significant predictor in solving routine problems and only the reasoning skill was a significant predictor in solving non-routine problems. Therefore, students should also be equipped with reasoning skill such as examining the cause-and-effect relationships by investigating the reason behind the decisions made while solving a problem, to contribute to the solution of non-routine problems.

KEY WORDS: non-routine problem; problem solving; routine problem; reflective thinking skills

\section{INTRODUCTION}

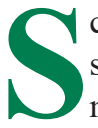
cience courses aim for students to attain key objectives such as collecting data from the physical environment, making observations, building and testing hypothesis, interpreting data, and presenting results (Sinan and Uşak, 2011). Students, therefore, gain research skills and are encouraged to investigate their living space, to observe problems, and to take the initiative to solve these problems (Y1lmaz, 2007). The literature has identified problems in different ways such as open-ended, context-based, complex, non-routine, and reallife problems (Akay et al., 2006; Maasz and O'Donoghue, 2011). This research sought to address the problems in the two categories: Routine and non-routine (Billstein et al., 1993; Nancarrow, 2004). Programme for International Student Assessment mainly tests student achievement on non-routine problems in various fields (OECD, 2014). Similarly, in Trends in International Mathematics and Science Study (TIMSS), the complete section of reasoning is composed of non-routine questions (Kolovou et al., 2009).

\section{Routine and Non-routine Problems}

Routine problems are the problems types in which a previously known method of solving -which is frequently encountered in textbooks - is sufficient (Asman and Markovits, 2009; Azak, 2015; Jonassen, 2010; Santos-Trigo and Camacho-Machín,
2009). Routine problems are related to learning procedures and definitions (Olkun and Toluk, 2003; Polya, 1962). Due to these characteristics of routine problems, a previously known method is beneficial for the solution (Altun et al., 2007; Jonassen, 2010; Polya, 1985); nevertheless, this is not applicable for non-routine problems (Selden et al., 1989; Stage and Kloosterman, 1992). Non-routine problems are not frequently encountered in textbooks, examinations, or classrooms. They contain situations which require a higher level of thinking than for routine problems and require the adaptation of prior knowledge to a new situation, therefore, not clearly solved (Kolovou et al., 2009; Schoenfeld, 1999). To solve this type of problem, students need to perform cognitive activities such as organizing and classifying data, recognizing the relationship between data, hypothesis, and making interpretations (Jurdak, 2005; Lee et al., 2014; Nancarrow, 2004).

\section{Difficulties Students Experience in Solving Non-routine Problems}

Noteworthy studies exist in the literature, which have reported negative aspects of students' problem-solving ability. Some studies have put forward that students, when encountering a problem, tend to reach the result by quickly making necessary calculations using the numbers given (Arslan and Altun, 2007; Dündar and Yaman, 2015; Iş1k and Kar, 2011). It has been emphasized that students are 
not competent in solving a problem, especially a nonroutine problem, using more than 1 strategy (Arslan and Yazgan, 2015; Artut and Tarım, 2006; 2009; Erdoğan, 2015; İncebacak and Ersoy, 2016). Other studies, however, have argued that students tend to solve non-routine problems as if they were routine (Chacko, 2004; Muir et al., 2008). As a result, students are less successful in solving non-routine problems (Altun et al., 2007; Asman and Markowitz, 2001; Çelik and Güler, 2013; Dündar and Yaman, 2015). Students' problem-solving strategies can be a factor affecting their level of success in solving non-routine problems (Elia et al., 2009). A student's use of strategy in a problem, even though it does not guarantee the solution, is considered important in terms of making the process guided. The level of this importance can increase depending on the structure of the different problem types, in particular (Mayer, 1992; Mintzberg, 1994). Problem solving is an important skill for science and mathematics education, as it is in daily life (Elia et al., 2009; Jonassen, 2000; Yenice, 2012).

\section{Problem Solving and Reflective Thinking Skills in the Science Course}

Solving a problem generally refers to addressing and evaluating the problem and reaching a solution (Heppner and Petersen, 1982). Problem-solving skills are related to skills such as scientific thinking, analytical thinking, data collection, and analyzing the data appropriate to its level (Gürsoy et al., 2015; Kalayc1, 2001). A problem-solving process also requires the use of strategic, procedural, and semantic knowledge (Mayer, 1992; Mayer and Hegarty, 1996). From this perspective, different knowledge and skills are important in problem solving (Güner and Alkan, 2011). Reflective thinking can be one of the skills related to problem solving in science courses (Albayrak and Şimşek, 2018; Karademir and Görgün, 2019; Kızılkaya and Aşkar, 2009; Shermis, 1992). Reflective thinking means the process of making analysis and judgment about the events taking place. Reflection can be identified as a students' learning experience, where they realize an in-depth understanding of the content encountered adopting a critical approach (Prensky and Berry, 2001; Strampel and Oliver, 2007). Reflective thinking, from the perspective of problem solving, is the habit of understanding a situation or a problem, generating alternative solutions to the problem, deciding important factors to be investigated, and evaluating the result (Baş, 2013; Erdoğan and Şengül, 2014; Kızılkaya and Aşkar, 2009; Michalsky and Kramarski, 2015).

This research addressed three problem solving skills: questioning, reasoning, and evaluating. In many studies, these three skills have been used as measurable sub-dimensions of reflective thinking skill perceptions of students toward problem-solving (Baş and Kıvılcım, 2013, Demirel et al., 2015; Köseoğlu et al., 2017; Kızılkaya and Aşkar, 2009). In the literature, questioning is defined as the process of seeking an answer to either the questions generated or to problems asked by others (Baki et al., 2012; Kızılkaya and Aşkar, 2009), whereas evaluating is described as the individual looking back to his actions again and determines the wrongs and the rights by making analyses (Karakoç and Demir, 2020; Kızılkaya and Aşkar, 2009). Finally, reasoning is the process of investigating the cause-and-effect relations because of the conclusion of why the reason for the action was performed (Kızılkaya and Aşkar, 2009). The aforementioned reflective thinking skills contribute to students' in-depth learning, conversely, insufficiency in these skills can cause deficiencies in the construction of meaningful knowledge in the problem-solving process (Song et al., 2006). Therefore, these dimensions are thought to be an important factor affecting the success of solving both routine and nonroutine problems.

\section{Research Significance and Purpose}

Students experience more difficulties in non-routine problems in the field of science. Many factors affect these difficulties. Studies in the literature have reported a relation between reflective thinking skills and academic achievement, belief, and attitude (Baş and Kıvılcım, 2013; Demirel et al., 2015; Köseoğlu et al., 2017; Kızılkaya and Aşkar, 2009). Although these studies are significant, no research has been encountered in the literature which examined the relation between reflective thinking skills toward problem solving and the level of solving routine and non-routine problems. Determining the effect of reflective thinking skills toward problem solving on the level of success in solving different types of problems can form a basis for the decisions teachers make in courses and contribute to increasing teaching quality. Therefore, this research aimed to determine the relation between reflective thinking skills toward problem solving and the level of solving routine and nonroutine problems. In addition, the research further examined whether the level of this relation varied by reflective thinking sub-skills and problem types.

\section{Research Question}

What is the relation between students' reflective thinking skills toward problem solving and their level of solving routine and non-routine science problems?

\section{METHODOLOGY OF RESEARCH}

\section{General Background}

This research was designed as descriptive research and aimed to determine the relation of eighth-grade students' reflective thinking skills toward problem solving and their level of solving routine and non-routine science problems (Balc1, 2009). Reflective thinking skills toward problem solving was measured as three sub-variables: Questioning, reasoning, and evaluating, according to the research model depicted in Figure 1. In addition, the research used routine and nonroutine problems to determine students' problem-solving levels. According to the research model (Figure 1), possible relations between students' scores on reflective thinking skills and their scores on the problem types were examined. The prediction level of students' reflective thinking skills was further examined according to the routine and non-routine problem types. 


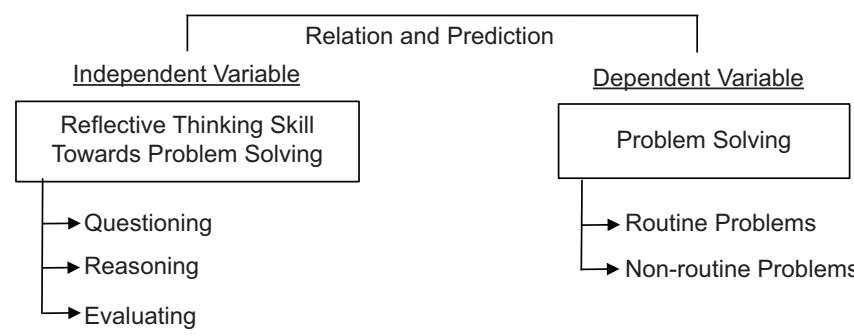

Figure 1: Model of the research (variables examined for a possible relation)

\section{Sample of Research}

Convenient sampling technique, a specific type of nonprobability sampling method, was used in the research. In this sampling technique, one or several subgroups of the population thought to be adequate are taken as a sample, instead of a representative sample of the population (Eryilmaz and Atak, 2011). In the convenient sampling technique, cases which are rich in terms of information necessary to perform a research are selected to carry out a deeper research (Özsoy and Özsoy, 2013). Therefore, schools that did not take this examination were identified and research permission was obtained from the national education for four of them. Instruments were applied to all eighth-grade students in four schools, however, some of the students did not complete the instruments. As a result, 408 eighth-grade students from four secondary schools in Kocaeli, Turkey, constituted the research sample.

Approval for the research was obtained from the Republic of Turkey's Ministry of National Education before starting data collection. Afterward, the teachers were informed about the aim of the research and how the research instruments were to be completed. Finally, the students who voluntarily agreed to participate in the research after being informed about its aim were asked to complete the instruments anonymously.

Table 1 shows the distribution of the students over the school types: 170 students from School I, 55 students from School II, 110 students from School III, and 73 students from School IV. Of the 408 students, 227 were male $(55.6 \%)$ and 181 were female $(44.4 \%)$. The average age of the students was found to be 14 .

\section{Instruments}

A "Routine Science Problems Test," "Non-Routine Science Problems Test," and a "Reflective Thinking Skills Toward Problem-Solving Questionnaire" (RTSTPQ) were used to collect data in the research.

\section{Routine science problems test}

The routine science problems test was developed by the researchers by selecting from problems published in the eighth-grade level of the TIMSS science examination (TIMSS, 2015). Science problems in the TIMSS examination regarding physics, chemistry, biology, and earth sciences as learning domains, and regarding knowing, applying, and reasoning as cognitive domains (Mullis et al., 2003). Knowledge level problems in TIMSS contain an individual's behaviors of

\begin{tabular}{llcc}
\hline $\begin{array}{l}\text { Table 1: Distribution of the participating in the research } \\
\text { by school and gender }\end{array}$ \\
\hline Variable & Categories & $\mathbf{n}$ & $\%$ \\
\hline School & School I & 170 & 41.2 \\
& School II & 55 & 13.5 \\
& School III & 110 & 27.5 \\
& School IV & 73 & 17.9 \\
Gender & Female & 181 & 44.4 \\
& Male & 227 & 55.6 \\
Total & & 408 & 100 \\
\hline
\end{tabular}

recognizing some characteristics of an object or phenomena, listing them when asked, or precisely repeating by rote (Mullis et al., 2003). Routine problems are the ones encountered in daily life and generally require the adaptation of a previously solved problem or a learned formula (Asman and Markovits, 2009; Azak, 2015; Jonassen, 2010; Santos-Trigo and CamachoMachín, 2009). For this reason, when the routine problems science test was developed, problems were selected from the knowing level of the cognitive domain in accordance with the science curriculum. The routine science problems test consisted of 15 problems, 13 multiple choices and 2 openended problems. A sample problem from the routine science problems test is presented in Figure 2.

The problem stated in Figure 2 is an example of a routine problem at the knowing level in TIMSS. Routine problems are the types of problems students frequently encounter in both the classroom environment and textbooks. For this reason, students can usually solve this problem easily since they may have solved a similar type of problem before. Routine problems necessitate students utilizing already acquired knowledge.

\section{Non-routine science problems test}

The non-routine science problems test was also developed by selecting problems from TIMSS science examination (TIMSS, 2015). While preparing this test, problems from the applying and reasoning levels of the cognitive domain in the TIMSS science examination were examined. Applying level problems contain an individual's application and solution to a new problem situation, using the knowledge obtained (Mullis et al., 2003). The apply level consists of two cognitive processes, doing and benefitting. In the doing process, when a student encounters a familiar test, they perform it in a routine way. The familiar situation provides the student hints which are usually sufficient for the selection of the activity suitable to be used. The benefitting process occurs when a student selects and uses an activity to perform a task which is not familiar to them (Krathwohl, 2002; Mullis et al., 2003). Since problems at this level can be appropriate to both the routine and non-routine problem types and with difficulty in making a distinction (Mullis et al., 2003), applying level problems were not used. Instead, problems at the reasoning level were selected. Reasoning level problems in TIMSS contain complex mental actions such as making a scientific inference, solving problems, developing an explanation, making a decision, and 


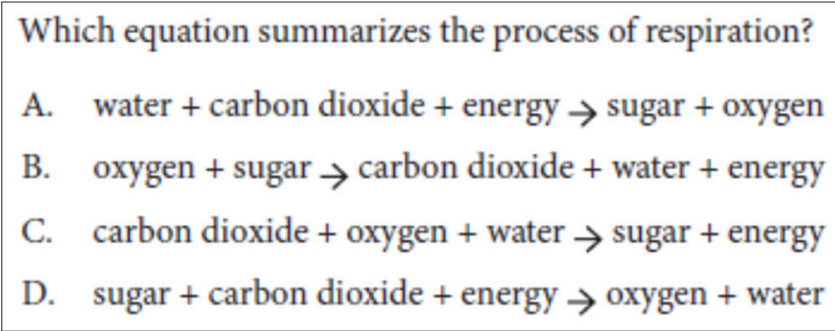

Figure 2: Question from the routine science problem test

adapting the knowledge to a new situation. At the reasoning level, students are expected to cope with solving unfamiliar or more complex problems by making inferences from scientific principles. This type of problems can be addressed as nonroutine problems since students are not familiar with them and it requires intuitive and inductive thinking (Mullis et al., 2003). The non-routine science problems test consisted of 15 problems, 4 multiple choices and 11 open-ended problems.

The problem in Figure 3 is an example of a non-routine problem at the reasoning level in TIMSS. Non-routine problems are problems types students are not familiar with. To solve this problem, the student needs to know the characteristics such as association and analysis, which is part of the reasoning level, and how to use them in the solution of the problem.

\section{RTSTPQ}

RTSTPQ used in the research was developed by Kizllkaya and Aşkar (2009). The questionnaire consisted of three dimensions: Questioning, reasoning, and evaluating. When the relation between the questionnaire dimensions was examined, a mutual relation was found at the value of $r=0.90$ between the dimensions of questioning and evaluating, $\mathrm{r}=0.82$ between the dimensions of evaluating and reasoning, and $\mathrm{r}=0.96$ between the dimensions of questioning and reasoning. The questionnaire was administered to 339 seventh-grade students (174 females and 165 males) and related statistical analyses were made. Confirmatory factor analysis was used for the obtained data. Kaiser-Meyer-Olkin (KMO) and Bartlett test were applied to determine the suitability of the data for the factor analysis. The KMO value was found to be 0.872 and Bartlett's test of sphericity value was found to be $1084.329(\mathrm{p}<0.01)$. The fit indices for the reliability study of the RTSTPQ were calculated as goodness-of-fit index (GFI) $=0.92$, adjusted GFI $=0.89$, non-normed fit index $=0.93$, comparative fit index $=0.95$, $\mathrm{RMSR}=0.08$, and root mean square error of approximation $=$ 0.071 . The questionnaire responses were given according to the following criteria: "Always=5," "Usually=4," "Sometimes=3," "Rarely=2," and "Never=1" (Kızılkaya and Aşkar, 2009).

\section{Data Collection}

Necessary information about the implementation was given to the administrators of the school before the data collection tools were administered. The students in the implementation classrooms were informed about the research aims and the students participated in the research on a volunteer basis. They were asked to respond to the questionnaire, routine problem test, and non-routine problem
Scientists think that the rocks in the picture were once a single rock.

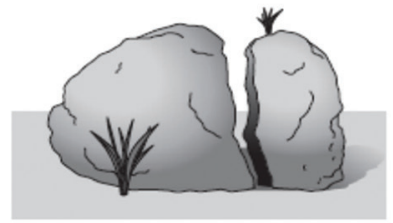

Which property of water had the most effect on splitting the rock into two pieces?

A. Water expanding when it freezes.

B. Water boiling at $100^{\circ} \mathrm{C}$.

C. Water having a density less than rock.

D. Water dissolving many substances.

Figure 3: Sample problem from the non-routine science problem test

test without revealing personal information like name-surname. During the implementations, any incomplete instrument was readministered by the school counselors and administrators and the researcher collected them a few days later. After students solved the routine problem test in one lesson hour, they completed the non-routine problem test in the second lesson hour. The students answered the questionnaire in the third lesson.

\section{Data Analysis}

According to research purpose first, simple correlation was used to analyze the relation between routine science problem solving and reflective thinking toward problem solving. Reflective thinking is divided into three dimensions: Questioning, reasoning, and evaluating. Therefore, three correlation values were calculated. Correlation analysis was also performed for relation between non-routine science problem solving and reflective thinking dimensions toward problem solving. Then, multiple linear regression was used to analyze to see which reflective thinking dimension has the highest correlation with routine/non-routine problem solving. In addition, to determine the relative importance order of the reflective thinking dimensions on solving routine and nonroutine problems, the standardized regression coefficient $(\beta)$ was calculated. Finally, $t$-test analysis was performed for the significance of regression coefficients.

\section{RESULTS OF RESEARCH}

The correlation analysis results presented in Table 2 revealed a positive significant relation between the routine problemsolving level and the questioning $(r=0.249 ; \mathrm{p}<0.01)$, reasoning $(r=0.226 ; p<0.01)$, and evaluating $(r=0.297$; $\mathrm{p}<0.01$ ) variables of the reflective thinking skills. A positive significant relation was similarly found between the nonroutine problem-solving level and the questioning $(\mathrm{r}=0.199$; $\mathrm{p}<0.01)$, reasoning $(\mathrm{r}=0.286 ; \mathrm{p}<0.01)$, and evaluating $(t=0.136 ; p<0.01)$ variables of the reflective thinking skills.

In summary, it can be asserted that as the students' reflective thinking toward problem solving scores increased, which 


\begin{tabular}{|c|c|c|c|c|}
\hline Reflective thinking & $\mathbf{n}$ & p & Routine & Non-routine \\
\hline Questioning & 408 & 0.001 & $0.249 * *$ & $0.199^{* *}$ \\
\hline Reasoning & 408 & 0.001 & $0.226^{* *}$ & $0.286^{* *}$ \\
\hline Evaluating & 408 & 0.001 & $0.297 * *$ & $0.136^{* *}$ \\
\hline
\end{tabular}

are identified as questioning, reasoning, and evaluating, their level of solving routine and non-routine problems also increased. The highest relation between the routine problems was observed with the evaluating variable and the lowest one with the reasoning variable. Contrary to the previous result, the highest relation between the non-routine problems was determined with the reasoning variable and the lowest one was observed with the evaluating variable. Multiple regression analysis results on the prediction of the routine problemsolving level according to the dimensions of the reflective thinking skills are given in Table 3.

As Table 3 shows the variables of questioning, reasoning, and, evaluating whose significant relation with the routine problemsolving level was determined, explained $10 \%$ of the total variance together $\left(R=0.323, R^{2}=0.104, F=15.695, \mathrm{p}<0.01\right)$. When the paired and partial correlations between the predictive variables and the dependent variable were examined, a positive relation was found between the questioning dimension and the level of solving routine problems $(r=0.249)$; however, the correlation between the other two variables was calculated as $r=0.081$. Similarly, there was a positive relation between the reasoning dimension and the level of solving routine problems $(r=0.226)$; however, the correlation between the other two variables was calculated as $r=0.076$. The positive paired correlation $(r=0.297)$, calculated between the dimension of evaluating and the level of solving routine problems, was found to preserve its significance when the other two variables were checked $(\mathrm{r}=0.172)$. According to the standardized regression coefficient $(\beta)$, the relative importance order of the predictive variables on solving routine problems is evaluating, questioning, and reasoning. The t-test results about the significance of the regression coefficients revealed that the evaluating variable was a significant predictor for solving routine problems $(t=3.520, p<0.01)$. The variables of questioning and reasoning, however, did not have a significant effect $\left(t_{\text {questioning }}=1.624, \mathrm{p}>0.05 ; t_{\text {reasoning }}=1.533, \mathrm{p}>0.05\right)$. Multiple regression analysis results on the prediction of the non-routine problem-solving level according to the dimensions of the reflective thinking skill are given in Table 4.

As Table 4 shows the variables of questioning, evaluating, and reasoning, whose significant relation with the routine problem-solving level was determined, explained $8 \%$ of the total variance together $\left(R=0.296, R^{2}=0.088, F=12.963\right.$, $\mathrm{p}<0.01)$. When the paired and partial correlations between the predictive variables and the dependent variable were
Table 3: Multiple regression analysis results about the prediction of the routine problem-solving level

\begin{tabular}{lccccccc}
\hline Variable & $\boldsymbol{B}$ & $\begin{array}{c}\text { Std. } \\
\text { Error }\end{array}$ & $\boldsymbol{\beta}$ & $\mathbf{t}$ & $\boldsymbol{p}$ & $\begin{array}{c}\text { Pearson } \\
\boldsymbol{r}\end{array}$ & $\begin{array}{c}\text { Partial } \\
\boldsymbol{r}\end{array}$ \\
\hline Constant & 3.096 & 0.812 & - & 3.812 & 0.00 & - & - \\
Questioning & 0.075 & 0.046 & 0.096 & 1.624 & 0.10 & 0.249 & 0.081 \\
Reasoning & 0.079 & 0.052 & 0.086 & 1.533 & 0.12 & 0.226 & 0.076 \\
Evaluating & 0.164 & 0.046 & 0.205 & 3.520 & 0.00 & 0.297 & 0.172 \\
\hline
\end{tabular}

$R=0.323, R^{2}=0.104 F(3-404)=15.695 \mathrm{P}=0.001$

Table 4: Multiple regression analysis results about the prediction of the non-routine problem-solving level

\begin{tabular}{lccccccc}
\hline Variable & $\boldsymbol{B}$ & $\begin{array}{c}\text { Std. } \\
\text { Error }\end{array}$ & $\boldsymbol{\beta}$ & $\mathbf{t}$ & $\mathbf{p}$ & $\begin{array}{c}\text { Pearson } \\
\boldsymbol{r}\end{array}$ & Partial $\boldsymbol{r}$ \\
\hline Constant & 3.011 & 0.973 & - & 3.094 & 0.02 & - & - \\
Questioning & 0.088 & 0.055 & 0.095 & 1.590 & 0.11 & 0.199 & 0.079 \\
Reasoning & 0.282 & 0.062 & 0.256 & 4.562 & 0.00 & 0.286 & 0.221 \\
Evaluating & 0.032 & 0.056 & 0.034 & 0.569 & 0.57 & 0.136 & 0.028 \\
\hline$R=0.296 R^{2}=0.088 F_{(3-404)}=12.963 \mathrm{P}=0.001$ & & &
\end{tabular}

examined, a positive relation was found between the questioning dimension and the level of solving non-routine problems $(r=0.199)$; however, the correlation between the other two variables was calculated as $r=0.079$. Similarly, there was a positive relation between the evaluating dimension and the level of solving routine problems $(\mathrm{r}=0.136)$; however, the correlation between the other two variables was calculated as $r=0.028$. The positive paired correlation $(r=0.286)$ (calculated between the dimension of reasoning and the level of solving non-routine problems) was found to preserve its significance when the other two variables were checked $(\mathrm{r}=0.221)$. According to the standardized regression coefficient $(\beta)$, the relative importance order of the predictive variables on solving non-routine problems is reasoning, questioning, and evaluating. The t-test results about the significance of the regression coefficients revealed that the reasoning variable was a significant predictor for solving non-routine problems $(t=4.562, p<0.01$. The variables of questioning and evaluating, however, did not have a significant effect $\left(t_{\text {questioning }}=1.590, \mathrm{p}>0.05 ; t_{\text {evaluating }}=0.569, \mathrm{p}>0.05\right)$.

\section{DISCUSSION}

The most fundamental result obtained in the research was that as the students' scores of reflective thinking toward problem solving increased, their level of solving routine and nonroutine problems also increased. The previous experimental studies have reported that reflective thinking skills positively affect academic success, problem-solving skills, and scientific process skills (Kızılkaya and Aşkar, 2009; Şahin, 2010; Tok, 2008; Yumuşak, 2017). Descriptive studies have also determined that there is a significant relationship between reflective thinking skills for problem-solving and success in science and mathematics (Baş, 2013; Baş and Kıvılcım, 2013; Albayrak and Şimşek, 2018). Relevant studies have 
reported that there is a relationship between three dimensions evaluating, reasoning, and questioning - and academic success; however, in some studies, the strongest predictor was found to be questioning, and in another study, only reasoning was found to be a significant predictor.

This research also found a relationship between these three dimensions and levels of solving routine and non-routine problems. However, when these relations were further examined in detail, the highest relation with routine problems was the evaluating variable and the lowest one was the reasoning variable. This occurred exactly opposite in the non-routine problems; the highest relation was observed in the reasoning dimension and the lowest relation was observed in the evaluating dimension. The regression analysis results showed that the evaluating skill is the only significant predictor for solving routine problems, while the reasoning skill is the only significant predictor for solving non-routine problems. It can be argued that there is not full agreement between the research results of the relevant studies, including this study (Baş and Kıvılcım, 2013; Baş, 2013; Albayrak and Şimşek, 2018). Furthermore, the related studies did not report in detail, which types of problems are used in their achievement tests. Therefore, the results obtained by these studies cannot be compared as high- or low-level learning. To interpret the results, the characteristics of the data collection tools used in the research were discussed.

According to this, among the items of the evaluating dimension of the reflective thinking skills questionnaire toward problemsolving, statements such as "I control my calculations after solving the problem and finding the answer" and "After solving the problem, I compare my solution with the solutions of my friends and evaluate my solution" were encountered. In this research, the evaluating dimension of reflective thinking is described as students' revision of their solution and their identification of mistakes and corrections (Kızılkaya and Aşkar, 2009). In addition, repetition of prior knowledge and the use of previously learned methods are considered sufficient in solving routine problems (Asman and Markovits, 2009; Jonassen, 2010; Polya, 1985; Santos-Trigo and Camacho-Machín, 2009). In other words, while solving this type of problem, if the solution method is known, the most important part of the solution is to carry out the steps of calculations without a mistake using a previously solved form (Jonassen, 2010; Polya, 1985). Based on the aforementioned characterization, the evaluating skill, compared to the skills of questioning and reasoning, showed more similarity with solving routine problems. In addition to this theoretical knowledge and based on the results obtained by the research, the reflective evaluation skill is thought to be an important predictive variable which contributes to the level of solving routine problems. However, the reflective evaluating skill was found to be a significant predictor of only the routine types of problems. This research indicated reflective reasoning skills as the significant predictor of the level of solving non-routine problems.
In this research, the reasoning skill included the processes where the student examined the cause-and-effect relation because of the conclusion on the reason for the action performed (Kızılkaya and Aşkar, 2009). Among the items in the reasoning dimension of the questionnaire used, statements such as "While solving a problem, I do my operations in consideration of why I do it," "I consider the reason for why I do every operation I do and attempt to relate it with the result I found," and "While solving a problem, I do every operation considering the previous and the next step" were encountered. Based on these statements, it can be said that the reflective reasoning skill is related to non-routine cognitive processes such as students' decision of which operation is made for what reason. In other words, the reasoning skill has the feature of contributing to the higher level thinking and the discovery of different solution methods, which are necessary in the solution process of routine problems (Bayazıt and Koçyiğit, 2017; Kolovou et al., 2009; Schoenfeld, 1999; Nancarrow, 2004). The solution process, rather than the result itself, is important in non-routine problems and it can be ascertained that the statements about the reasoning dimension in the reflective thinking questionnaire are connected with this situation. Therefore, this research concluded that the reasoning skill of reflective thinking toward problem solving is an important variable contributing to the level of solving non-routine problems.

Another result obtained by the research was that the reflective questioning skill had no significant effect on the level of solving both routine and non-routine problems. Questioning contains the process of seeking an answer to either the problems one generates or to problems asked by the environment (Baki et al., 2012; Kızılkaya and Asskar, 2009). Among the items in the questioning dimension of the questionnaire used statements such as "When I could not solve a problem, I ask questions to myself to understand why I could not solve it" and "When I read the problem, I ask questions to myself to determine what is given and asked" were encountered. The aforesaid statements involve the reflective thinking processes where the students posed questions to themselves while solving the problem. This research, however, did not put forth any significant contribution of reflective behaviors related to students' self-questioning to the level of solving both routine and non-routine problems. Many factors may have affected this result. One of them could be that students used the behavior of posing questions to themselves to be more effective in the processes such as understanding the problem, creating possible solution methods, and using the solution methods while solving a problem. Stemming from such factors, this research may have found the result that reflective questioning skills have no significant effect on the students' solution of both routine and non-routine problems.

\section{CONCLUSIONS}

This study determined that success in routine problemsolving was only affected by the "reflective evaluation" skill 
and success in non-routine problems only by the "reflective reasoning" skill. Some recommendations were provided to the implementers in terms of both routine and non-routine problems based on these study results.

Reflective evaluation skills are cognitive functions of students such as reviewing their actions, determining rights and wrongs, evaluating repeatedly, and trying to solve the next problem better. Therefore, a recommendation is made for teachers to include teaching methods that encourage the "evaluation" skill in class when needed in terms of routine problems. Students can be given opportunities to practice solving routine problems using methods of which the main purpose is practice and reinforcement such as lecturing and exercise-based teaching. By initiating these teaching methods, students can be facilitated in acquiring competence in result-oriented cognitive functions, such as reviewing decisions made during problem solving and determining rights and wrongs made during the solution process. This is associated with routine problems; however, process-oriented cognitive functions are more important for non-routine problems.

Therefore, it is further recommended to include teaching methods supporting students' causal reasoning skills in terms of non-routine problems. Cognitive functions such as discovering different solutions and forming cause-effect relationships are important during the solution process of non-routine problems. Instead of imitating previously learned solutions, instructional methods such as discovery learning, case studies, and discussion methods that encourage creating new solutions by understanding the problem are recommended in the teaching processes. These teaching methods can help students acquire competence in inductive reasoning skills, such as understanding the intent of the problem, deciding on the necessary information, determining the solution, and finding the relationship between them.

Finally, recommendations for the researchers include carrying out experimental studies on determining the effect of the above-mentioned teaching methods on the solving success of routine and non-routine problems. Moreover, it is also recommended to carry out studies aimed at determining the effect of a curriculum focused on developing reflective thinking skills of students on problem-solving success.

\section{REFERENCES}

Akay, H., Soybaş, D., \& Argün, Z. (2006). Problem posing experiences and using open-ended questions in mathematics teaching. Kastamonu Education Journal, 14(1), 129-146.

Albayrak, M., \& Şimşek, M. (2018). The predictive power to mathematical success of belief and reflective thinking for problem solving. Journal of Human Sciences, 15(2), 807-815.

Altun, M., Memnun, D.S., \& Yazgan, Y. (2007). Primary school teacher trainees' skills and opinions on solving non-routine mathematical problems. Elementary Education Online, 6(1), 127-143.

Arslan, C.., \& Altun, M. (2007). Learning to solve non-routine mathematical problems. Elementary Education Online, 6(1), 50-61.

Arslan, C., \& Yazgan, Y. (2015). Common and flexible use of mathematical non routine problem solving strategies. American Journal of Educational Research,3(12), 1519-1523.
Artut, P.D., \& Tarım, K. (2006). Investigation of the elementary school students' problem solving levels, problem solving strategies and error types in the non-routine word problems. Çukurova University Institute of Social Sciences, 15(2), 37-50.

Artut, P.D., \& Tarım, K. (2009). Investigation of the prospective teachers' problem solving process in the non-routine word problems. Journal of Uludag University of Faculty of Education, 22(1), 53-70.

Asman, D., \& Markovits, Z. (2009). Elementary school teachers' knowledge and beliefs regarding non-routine problems. Asia Pacific Journal of Education, 29(2), 229-249.

Azak, S. (2015). Determination of Strategies and Metacognitive Skills used by Secondary School $8^{\text {th }}$ Grade Students in Problem Solving, Unpublished Master's Thesis. Trabzon: Karadeniz Technical University.

Baki, A., Güç, F.A., \& Özmen, Z.M. (2012). The investigation of pre-service mathematic teachers' reflective thinking skills toward problem solving. International Journal of Curriculum and Instructional Studies, 2(3), 59-72.

Balci, A. (2009). Sosyal Bilimlerde Araştırma (Research in Social Sciences). Turkey: Pegem A Publishing.

Baş, G. (2013). Investigating the correlation between elementary students' reflective thinking skills towards problem solving and academic success in science and technology course with structural equation modeling. HAYEF Journal of Education, 10 (2), 1-12.

Baş, G., \& Kıvılcım, Z.S. (2013). The correlation between reflective thinking skills towards problem solving and academic success in mathematics and geometry courses of high school students. Journal of Kirsehir Education Faculty, 14(3), 1-17.

Bayazıt, İ., \& Koçyiğit, N. (2017). A comparative analysis of gifted and nongifted students' achievements in the context of non-routine problems. Abant Izzet Baysal University Journal of Education Faculty. 17(3), 1172-1200.

Billstein, R., Libeskind, S., \& Lott, J.W. (1993). A Problem Solving Approach to Mathematics for Elementary School Teachers. $5^{\text {th }}$ ed. United States: Addison-Wesley.

Çelik, D., \& Güler, M. (2013). Examination of realistic problem solving skills of sixth grade students. Dicle University Journal of Ziya Gökalp Faculty of Education, 20, 180-195.

Chacko, I. (2004). Solution of real-world and standard problems by primary and secondary school students: AZimbabwean example. African Journal of Research in Mathematics, Science and Technology Education, 8(2), 91-103.

Demirel, M., Derman, I., \& Karagedik, E. (2015). A study on the relationship between reflective thinking skills towards problem solving and attitudes towards Mathematics. Procedia-Social and Behavioral Sciences, 197, 2086-2096.

Dündar, S., \& Yaman, H. (2015). How do prospective teachers solve routine and non-routine trigonometry problems? International Online Journal of Educational Sciences, 7(2), 41-57.

Elia, I., van den Heuvel-Panhuizen, M., \& Kolovou, A. (2009). Exploring strategy use and strategy flexibility in non-routine problem solving by primary school high achievers in mathematics. ZDM Mathematics Education, 41(5), 605.

Erdoğan, A. (2015). Turkish primary school students' strategies in solving a non-routine mathematical problem and some implications for the curriculum design and implementation. International Journal for Mathematics Teaching and Learning, 1-27.

Erdoğan, F., \& Şengül, S. (2014). The investigation of pre-service elementary mathematics teachers' reflective thinking levels. Asian Journal of Instruction, 2(1), 18-30.

Eryilmaz, A., \& Atak, H. (2011). Investigation of starting romantic intimacy in emerging adulthood in terms of self-esteem, gender and gender roles. Educational Sciences: Theory and Practice, 11(2), 595-600.

Güner, N., \& Alkan, V. (2011). The errors students from primary education and secondary education done while answering 2010 YGS-mathematics problems. Pamukkale University Journal of Education, 30(30), 125-140.

Gürsoy, K., Güler, M., Bülbül, B., \& Güven, B. (2015). Awareness of $9^{\text {th }}$ graders regarding word problems with missing and extra information. Journal of Subject Teaching Research, 1(1), 13-22.

Heppner, P.P., \& Petersen, C.H. (1982). The development and implications of a personal problem-solving inventory. Journal of Counseling 
Psychology, 29(1), 66.

İncebacak, B.B., \& Ersoy, E. (2016). Problem solving skills of secondary school students. China-USA Business Review, 15(6), 275-285.

Işık, C., \& Kar, T. (2011). Investigating of the number perception and nonroutine problem solving skills of $6^{\text {th }}, 7^{\text {th }}$ and $8^{\text {th }}$ grade students. Ahi Evran University Faculty of Education, 12(1), 57-72.

Jonassen, D. (2010). Learning to Solve Problems: A Handbook for Designing Problem-Solving Learning Environments. London: Routledge.

Jonassen, D.H. (2000). Toward a design theory of problem solving. Educational Technology Research and Development, 48(4), 63-85.

Jurdak, M. (2005). Contrasting perspectives and performance of high school students on problem solving in real world situated, and school contexts. Educational Studies in Mathematics, 63(3), 283-301.

Kalaycı, N. (2001). Sosyal Bilgilerde Problem Çözme ve Uygulamalar (Problem Solving and Applications in Social Studies). Karnataka: Gazi Bookstore.

Karademir, Ç.A., \& Görgün, S. (2019). Investigation of secondary school students' reflective thinking skills for problem solving and selfregulation skills. International Journal of Eurasian Researches, 7(16), 292-313.

Karakoç, C., \& Demir, Ö. (2020). The predictive power of Turkish teachers' reflective thinking skills perceptions in their problem solving skills perceptions. International Journal of Education and Literacy Studies, $8(3), 12-24$.

Kızılkaya, G., \& Aşkar, P. (2009). The development of a reflective thinking skill scale towards problem solving. Education and Science, 34(154), 82-92.

Kolovou, A., van den Heuvel-Panhuizen, M., \& Bakker, A. (2009). Non-routine problem solving tasks in primary school mathematics textbooks-a needle in a haystack. Mediterranean Journal for Research in Mathematics Education, 8(2), 31-68.

Köseoğlu, E., Demirci, F., Demir, B., \& Özyürek, C. (2017). The examination of $7^{\text {th }}$ grade students' reflective thinking skills towards problem solving: A sample of Ordu City. International E-Journal of Educational Studies, $1(1), 60-68$

Krathwohl, D.R. (2002). A revision of Bloom's taxonomy: An overview. Theory into Practice, 41(4), 212-218.

Lee, N.H., Yeo, D.J.S., \& Hong, S.E. (2014). A metacognitive-based instruction for primary four students to approach non-routine mathematical word problems. ZDM, 46(3), 465-480.

Maasz, J., \& O’Donoghue, J. (2011). Real-World Problems for Secondary School Mathematics Students: Case Studies. Germany: Sense Publisher.

Mayer, R.E. (1992). Thinking, Problem Solving, Cognition. $2^{\text {nd }}$ ed. United States: Freeman and Co.

Mayer, R.E., \& Hegarty, M. (1996). The process of understanding mathematical problem solving. In: Sternberg, R.J., \& Ben-Zeev, T., (Eds.), The Nature of Mathematical Thinking. United States: Erlbaum. pp. 29-54.

Michalsky, T., \& Kramarski, B. (2015). Prompting reflections for integrating self-regulation into teacher technology education. Teachers College Record, 117(5), 1-38.

Mintzberg, H. (1994). The fall and rise of strategic planning. Harvard Business Review, 72(1), 107-114.

Muir, T., Beswick, K., \& Williamson, J. (2008). I'm not very good at solving problems: An exploration of students' problem solving behaviours. The Journal of Mathematical Behavior, 27(3), 228-241.

Mullis, I.V., Martin, M.O., Smith, T.A., Garden, R.A., Gregory, K.D., Gonzalez, E.J., Chrostowski, S.T., \& O'Connor, K.M. (2003). TIMSS Trends in Mathematics and Science Study: Assessment Frameworks and Specifications 2003. Netherlands: International Association for the Evaluation of Educational Achievement.

Nancarrow, M. (2004). Exploration of Metacognition and Non-Routine Problem Based Mathematics Instruction on Undergraduate Student Problem-Solving Success, Unpublished Doctoral Thesis. Florida: The Florida State University.

OECD. (2014). PISA 2012 results: Creative problem solving: Students' skills in tackling real-life problems. Organisation for Economic Cooperation and Development, 1(5), 1-252.

Olkun, S., \& Toluk, Z. (2003). Illkögrretimde Etkinlik Temelli Matematik Ögretimi (Activity Based Mathematics Teaching in Primary Education). Turkey: Anı Publishing.

Özsoy, S., \& Özsoy, G. (2013). Effect size reporting in educational research. Elementary Education Online, 12(2), 334-346.

Polya, G. (1962). Mathematical Discovery: On Understanding, Learning, and Teaching Problem Solving. United States: John Wiley \& Sons.

Polya, G. (1985). How to Solve it. New Jersey: Princeton University Press.

Prensky, M., \& Berry, B.D. (2001). Do they really think differently. On the Horizon, 9(6), 1-9.

Şahin, A. (2010). The effect of instructing teaching techniques to Turkish teacher candidates by reflective teaching activities on academic success Research of Eastern Anatolia Region, 9(1), 28-33.

Santos-Trigo, M., \& Camacho-Machín, M. (2009). Towards the construction of a framework to deal with routine problems to foster mathematical inquiry. Primus, 19(3), 260-279.

Schoenfeld, A.H. (1999). Looking toward the $21^{\text {st }}$ century: Challenges of educational theory and practice. Educational Researcher, 28(7), 4-14.

Selden, J., Mason, A., \& Selden, A. (1989). Can average calculus students solve non routine problems? Journal of Mathematical Behavior, 8, 45-50.

Shermis, S.S. (1992). Critical Thinking: Helping Students Learn Reflectively. Bloomington: EDINFO Press.

Sinan, O., \& Uşak, M. (2011). Evaluating of prospective biology teachers' scientific process skills. Mustafa Kemal University Journal of Social Sciences Institute, 8(15), 333-348.

Song, H.D., Grabowski, B.L., Koszalka, T.A., \& Harkness, W.L. (2006). Patterns of instructional-design factors prompting reflective thinking in middle-school and college level problem-based learning environments. Instructional Science, 34(1), 63-87.

Stage, F.K., \& Kloosterman, P. (1992). Measuring beliefs about mathematical problem solving. School Science and Mathematics, 92(3), 109-115.

Strampel, K., \& Oliver, R. (2007). Using Technology to Foster Reflection in Higher Education. Available from: https://www.researchgate.net/ publication/49277756_using_technology_to_foster_reflection_in_ higher education.

TIMSS. (2015). TIMSS and PIRLS International Study Center. Available from: http://www.timss.bc.edu.

Tok, S. (2008). The effects of reflective thinking activities in science course on academic achievements and attitudes toward science. Elementary Education Online, 7(3), 557-568.

Yenice, N. (2012). Investigating the self-efficacy and problem-solving skills of Preservice teachers. Electronic Journal of Social Sciences, 11(39), 36-58.

Yılmaz, F. (2007). İlköğretimde 1. kademede bilimsel tutum ve davranış kazandırmada fen bilgisi dersinin etkililiğgine ilişkin öğretmen görüşleri (Teachers' views on the effectiveness of science course in gaining scientific attitude and behavior). Elementary Education Online, 6(1), 113-126.

Yumuşak, G.K. (2017). The effects of reflective thinking activities on science process skills. Necatibey Faculty of Education, Electronic Journal of Science and Mathematics Education, 11(1), 222-251. 